\title{
Investment Property in the Financial Statements of Capital Groups Listed on the Warsaw Stock Exchange
}

Piotr Prewysz-Kwinto

WSB University in Torun, Department of Finance and Accounting Poland, ppqq@poczta. onet. pl

Grażyna Voss

University of Technology and Life Sciences, Faculty of Management, Bydgoszcz, Poland, gvoss@wp. pl

\begin{abstract}
In recent years, investing in property has become very popular. It is related to a significant decrease in interest rates, which has resulted in a decrease in interest rates on bank deposits and risk-free securities. What is more, this kind of investment seems to be less risky than investing in shares or raw materials due to a steady increase in property prices in Poland in the recent years. Investment property owned by an entity conducting business activity must be properly presented in financial statements, which is next reflected in the evaluation of financial position. Recognition, measurement and presentation of investment property in financial statements have been comprehensively prescribed in International Accounting Standard 40 - Investment Property, which was released in December 2003. It was first applied to financial statements prepared for the reporting period starting after January 1, 2005. The standard was revised twice - first in 2008 and then in 2013. The aim of this paper is to describe the recognition, measurement and disclosure of investment property under polish and international accounting regulations as well as to analyze the presentation of such information in financial statements of the largest companies listed on the Warsaw Stock Exchange. The main methods used include the analysis and evaluation of legal acts and subject-related literature as well as the analysis of information disclosed in financial statements of the largest companies listed on the Warsaw Stock Exchange
\end{abstract}

Keywords: investment property, International Accounting Standard, accounting regulations, measurement methods.

\section{Introduction}

1. Description of investment property and its measurement methods

The primary legal act in Poland which prescribes accounting principles, including preparation of financial statements, is the Polish Accounting Act of September 29, 1994'. According to this Act, some entities (including capital groups which issue securities admitted to one of the regulated markets of the European Economic Area) are required to prepare their financial statements in accordance with the international standards IAS/ IFRS, which may differ from the principles specified in the Act.

\section{1. Investment property under the Polish Accounting Act}

The Polish Accounting Act does not directly define investment property, but there is a reference to investment property in the definition of investments. According to Section 3.1.17 of the Act, investments are understood to mean assets held by an entity in order to derive economic benefits from them as a result of an increase in their value, to gain income in the form of interest, dividends (shares in profits) or other benefits, including those from commercial transactions. In particular,

\footnotetext{
${ }_{1}^{1}$ Polish Accounting Act of 29 September 1994, Polish Journal of Law, items 330 and 613.
} 
investments include financial assets as well as properties and intangible assets which are not used by an entity for its primary business.

Therefore, investment property means property which earns profit for its owner or user (e. g. under finance lease) as a result of an increase in its value or other benefits derived from holding it (e. g. in the form of rent or lease of land, buildings or premises), including benefits from commercial transactions

The criterion which distinguishes investment property from property included in tangible assets is the purpose for which the property is held, regardless whether it was acquired, manufactured, apportioned or reclassified from tangible assets ${ }^{1}$. Moreover, in the statement of cash flows cash received from investment property is separated from other assets held by an entity which are used for operating activity ${ }^{2}$. A method of recording investment property depends on the adopted measurement method ${ }^{3}$.

According to Section 28. 1. 1a of the Polish Accounting Act, investment property should be measured at least at the end of the reporting period in two possible manners: according to the rules applicable to tangible assets or at a market price/fair value and it should be applied to all investment property held by an entity. A description of available measurement methods is presented in Table 1.

Table 1. Measurement methods of investment property under the Polish Accounting Act

\begin{tabular}{|l|l|l|}
\hline $\begin{array}{l}\text { Measurement } \\
\text { method }\end{array}$ & $\begin{array}{l}\text { Measurement according to the rules applicable } \\
\text { to tangible assets }\end{array}$ & Measurement at a market price/ fair value \\
\hline $\begin{array}{l}\text { Measurement } \\
\text { manner }\end{array}$ & $\begin{array}{l}\text { In the statement of financial position } \\
\text { investment property is recognised at its cost or } \\
\text { at a revalued amount (after revaluation) plus } \\
\text { improvement costs and less depreciation } \\
\text { charges and impairment loses. }\end{array}$ & $\begin{array}{l}\text { The value of investment property means an } \\
\text { asset's fair value less costs to sell at the } \\
\text { end of the reporting period. }\end{array}$ \\
\hline
\end{tabular}

Source: author's compilation based on the Polish Accounting Act.

\section{2. Investment property under IAS 40}

IAS 40 defines two terms related to properties. They are: investment property and owner-occupied property. Investment property is understood to mean property (land or a building - or a part of a building - or both) held by the owner or by the lessee under a finance lease to earn rentals or for capital appreciation or both, rather than for:

a) use in production or supply of goods or services, or for administrative purposes; or

b) sale in the ordinary course of business.

According to Section 8 of IAS 40, investment property may include the following:

a) land held for long-term capital appreciation rather than for short-term sale in the ordinary course of business;

b) land held for a currently undetermined future use;

c) land held by an entity (or held by an entity under a finance lease) and leased out under one or more operating leases;

d) a building that is vacant but is held to be leased out under one or more operating leases.

Investment property is recognised as an asset only when:

\footnotetext{
1 W. Gabrusewicz (ed.), Rachunkowość finansowa dla profesjonalistów, SKwP, Warszawa 2011, p. 106.

2 J. Turyna, Standardy Sprawozdawczości Finansowej, MSSF, US GAAP, polskie ustawodawstwo, Difin, Warszawa 2006 r, p. 169.

${ }^{3}$ G. K. Świderska (ed.), Wzorcowy plan kont z komentarzem do ustawy o rachunkowości i Międzynarodowych Standardów

Rachunkowości, Wolters Kluwer business, Warszawa 2012, p. 101.
} 
a) it is probable that the future economic benefits associated with the investment property will flow to the entity, and

b) the cost of the investment property can be measured reliably.

According to the discussed Standard, investment property is initially measured at its cost, including transaction costs such as: fees for legal services, property transfer taxes or notary fees. According to Section 23 of the Standard, the cost of an investment property may not be increased by start-up costs, operating loses incurred before the investment property achieves the planned level of occupancy or abnormal costs incurred during construction or development of the property.

After initial recognition, for measurement at the end of the reporting period an entity may choose one of two methods, i. e. : the fair value model or the cost model as is the case for tangible assets ${ }^{1}$. It is important that the chosen model is applied too all investment property. The only exception is the situation when an entity applies the fair value model and there is clear evidence that the entity cannot reliably determine the fair value of a specific property on a continuing basis. In such an exceptional case the entity may apply the cost model. The model must then be applied until disposal of the investment property (Section 53 of the Standard).

It should be underlined that the use of the cost model does not relieve an entity from the requirement to determine the fair value of the property as according to the Standard, such value should be disclosed in the notes to financial statements.

It should be indicated here that fair value measurement is an ambiguous term and the use of such measurement is related to a combination of various measurement methods, as a result of which economic entities may present their assets and financial situation in financial statements in a fair and reliable manner ${ }^{2}$. The rules to determine fair value have been prescribed by a new financial reporting standard - IFRS 13 Fair Value Measurement, effective since 2013. According to the Standard, fair value is the price that can be received from the sale of an asset or paid to transfer a liability in an orderly transaction between market participants at the measurement date ${ }^{3}$. The rules to determine fair value are subject to available information and have been divided into three levels of measurement under IFRS 13, i. e. : 4 :

- level I - information obtained from active markets, it is the source of the most reliable data,

- level II - information not obtained from active markets, but observable, i. e. objective and measurable,

- level III - data unobservable, this level is applied when information from the first two levels cannot be obtained.

In the course of an entity's operation there might be a change in use of its property, which results in a transfer of specific assets to or from investment property. It is possible provided that the change is use of such assets is evidenced by:

a) commencement of owner-occupation - for a transfer from investment property to owner-occupied property;

b) commencement of development with a view to sale - for a transfer from investment property to inventories;

c) end of owner-occupation - for a transfer from owner-occupied property to investment property;

d) commencement of an operating lease to another party - for a transfer from inventories to investment property; or

e) completed construction or development of property - for a transfer from property under construction (under IAS 16) to investment property.

\footnotetext{
${ }^{1}$ MSR 40 - Międzynarodowy Standard Rachunkowości 40 - Nieruchomości Inwestycyjne z dnia 29.11.2008, Dziennik Urzędowy Unii Europejskiej, L. 320/323,

${ }^{2}$ A. Karmańska (ed.), Ryzyko w rachunkowości, Difin, Warszawa 2008, p. 347.

${ }_{3}^{3}$ IFRS 13 - Fair Value Measurement, http://www.iasplus.com/en/standards/ifrs/ifrs13 (25.07.2015).

${ }^{4}$ P. Prewysz-Kwinto, G. Voss, Wykorzystanie MSSF 13 wycena w wartości godziwej w polskich przedsiębiorstwach - wyniki badania ankietowego, „Współczesne problemy rachunkowości w teorii i praktyce”, Wydawnictwo Uniwersytety Warmińsko-Mazurskiego w Olsztynie, Olsztyn 2014, p. 98.
} 
One should remember that if an entity uses fair value measurement, a transfer of a property between specific assets may result in a change of the asset's carrying amount, and such changes are directly recognised in the financial result.

Finally, it should be indicated that under IAS 40 , every entity is required to disclose various information on investment property in its financial statements. The scope of the disclosures is specified in Sections 74-79 and depends on the adopted measurement model. The most significant disclosures include:

adopted measurement model,

in difficult cases beyond the scope of the standard, the criteria an entity uses to distinguish investment property from property held by the owner,

adopted methods for determining fair value,

indication whether fair value is determined by an independent valuer who holds a recognised professional qualification or measurement is made by the entity,

amounts recognised in profit or loss for: rental income from investment property, direct operating expenses (including repairs and maintenance) arising from investment property that generated rental income and separately those arising from investment property that did not generate rental income.

2. Investment property in the largest companies listed on the Warsaw Stock Exchange

\section{1. Study methodology and study group}

The study included the largest capital groups listed on the Warsaw Stock Exchange, i. e. those groups which on August 1 , 2015, were included in WIG 30 index ${ }^{1}$. For purposes of the analysis, the entities were divided according to the type of conducted business activity, and the results are presented in Table 2.

Table 2. Analysed entities according to the type of conducted business activity

\begin{tabular}{|l|l|l|l|}
\hline Item no. & Industry & Number of companies & Share \\
\hline 1 & Chemical & 5 & $16.7 \%$ \\
\hline 2 & Energy & 4 & $13.3 \%$ \\
\hline 3 & Financial services & 8 & $26.7 \%$ \\
\hline 4 & Mass media & 2 & $6.7 \%$ \\
\hline 5 & Textile & 2 & $6.7 \%$ \\
\hline 6 & Mining & 4 & $13.3 \%$ \\
\hline 7 & Other & 5 & $16.7 \%$ \\
\hline 8 & Total & 30 & $100.0 \%$ \\
\hline
\end{tabular}

Source: author's compilation.

The entities with the biggest share in the study group included those entities which provided financial services, among which commercial banks were dominant. Item Other included capital groups representing the following industries: IT, telecommunications, retail trade, food and real estate. In accordance with the Polish Accounting Act, all entities, being capital groups listed on the stock exchange, prepared financial statements under international standards IAS/ IFRS, and the analysis included both consolidated and separate financial statements prepared for fiscal year 2014 or fiscal year which ended in 2014.

\section{2. Study results}

The study started with ascertaining whether the entities under the study held investment property and recognised it in financial statements. The analysis was performed based on disclosures in consolidated financial statements and the results are presented in charts 1 and 2 .

\footnotetext{
${ }^{1}$ WIG30 index has been calculated since September 23, 2013 based on the value of portfolio of 30 major and most liquid companies on the WSE Main List.
} 


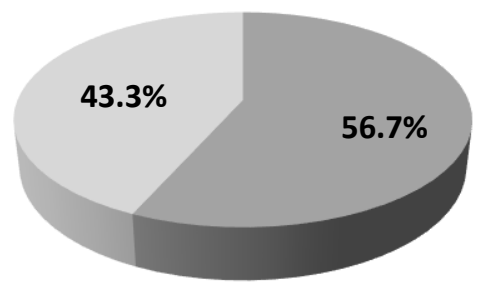

entities holding investment properties

entities do not have investment properties

Chart. 1. Percentage of analysed companies holding or not holding investment property

Source: author's compilation.

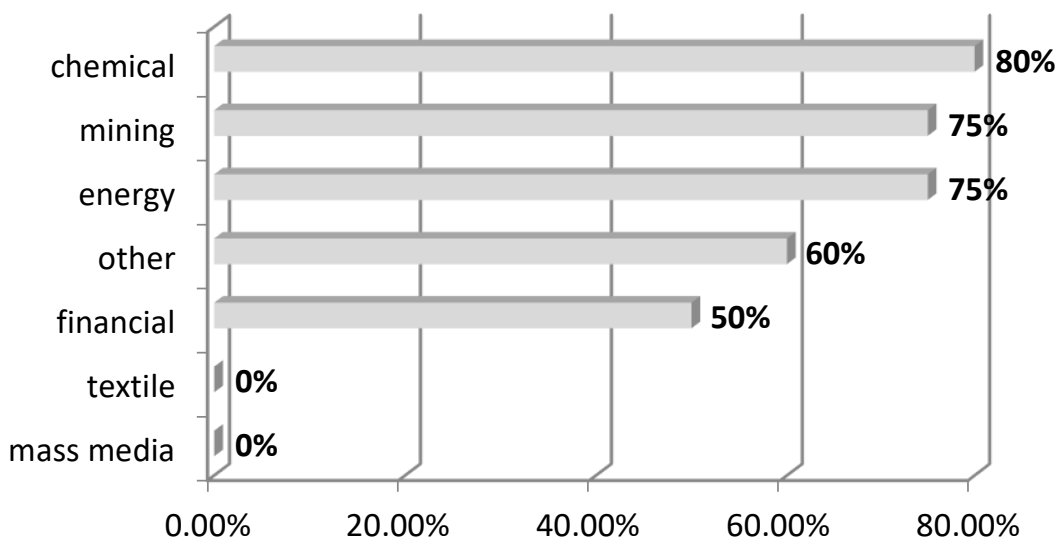

Chart. 2. Percentage of analysed companies holding investment property in relation to conducted business activity Source: author's compilation.

Almost $57 \%$ of the analysed entities held investment property. The analysis of the results based on the type of conducted business activity (Chart. 2) shows that the percentage of entities which held investment property was the highest in chemical $(80 \%)$, mining and energy (75\% each) industries. None of the capital groups from mass media and textile industries held investment property. All entities which held the analysed item of assets presented detailed information on its measurement method in their accounting policy which was included in the

Introduction to financial statements. Descriptions presented by most of the analysed entities included definitions of investment property, applied initial measurement method and measurement at the end of the reporting period as well as methods of recognising measurement differences in financial statements. Moreover, such information was also disclosed in financial statements of two groups which did not hold investment property.

All analysed entities which held investment property presented it in detail in the notes to consolidated financial statements. The disclosed information usually included a list of investment property, its value at the beginning and at the end of the fiscal year, and a detailed list of changes resulting from acquisition or sale of assets, reclassifications as well as adjustments directly related to the applied measurement method. What is more, $60 \%$ of the entities which held investment property also presented income generated by such assets in the fiscal year in the notes, e. g. rental charges and related maintenance costs. 
It is worth indicating that for more than $80 \%$ of the analysed entities investment property did not constitute a significant item of total assets.

The aim of the next stage of the analysis was to ascertain which investment property measurement methods were applied by the entities. The results are presented in Table 3.

Table 3.. Investment property measurement methods applied by the analysed entities

\begin{tabular}{|l|l|l|l|}
\hline $\begin{array}{l}\text { Item } \\
\text { no. }\end{array}$ & Measurement method & Measurement at recognition & $\begin{array}{l}\text { Measurement at the end of } \\
\text { the reporting period }\end{array}$ \\
\hline 1 & Cost & $89.5 \%$ & $63.2 \%$ \\
\hline 2 & Fair value & $10.5 \%$ & $36.8 \%$ \\
\hline 3 & Total & $100 \%$ & $100 \%$ \\
\hline
\end{tabular}

Source: author's compilation.

For the majority of the analysed entities, investment property at initial recognition (i. e. receipt of a given asset) was measured at its cost plus transaction costs. Barely $10 \%$ of the analysed entities applied the fair value model at initial recognition. The situation was different when measurement methods at the end of the reporting period were analysed. More than one third of the analysed entities used measurement at present value, i. e. the fair value model whereas less than two thirds of the entities measured investment property in the same way as tangible assets, i. e. at cost less accumulated depreciation charges and impairment loses (historical cost principle). It is worth mentioning that all companies which applied the fair value model additionally indicated that for assets which could not be measured at fair value, the same measurement as for tangible assets was used.

A more detailed analysis of the results shows that the fair value model at the end of the reporting period was mainly applied by chemical industry companies $(75 \%$ of the entities presented information on investment property measurement method in their accounting policy) and financial services companies (40\%). None of the groups from the mining industry applied the fair value model.

What should be underlined here is the fact that only three from the capital groups which used the fair value model presented a more detailed description of the model in their accounting policy. The description indicated the level of measurement in the fair value hierarchy ${ }^{1}$ and provided details on applied measurement methods. In all cases either the second or the third level of fair value measurement was used and the entities applied either market approach (comparing prices of comparable investment property - usually applied for measurement of investment property land) or income approach (the total of discounted cash flow generated by investment property). Moreover, in all cases investment property was valued by independent valuers and the resulting measurement differences, both gains and losses, were immediately recognised in the statement of comprehensive income.

It is worth mentioning that the groups which measured and presented investment property in the same way as tangible assets (at historical cost) also had such assets valued by independent valuers and disclosed such information in the detailed notes to financial statements. Half of the companies using historical cost measurement included such information in their financial statements.

\section{Investment property in Globe Trade Centre S. A. ${ }^{2}$}

Globe Trade Centre S. A. is one of the capital groups listed on the WSE and included in WIG-30 index, and is one of the leading companies in the real estate sector in Central, Eastern and Southern Europe. The company was founded in 1994

\footnotetext{
${ }^{1}$ IFRS 13 Fair Value Measurement sets out three levels of measurement, depending on the available information. For further details see: P. Prewysz-Kwinto, G. Voss, Wykorzystanie MSSF 13 Wycena w wartości godziwej w polskich przedsiębiorstwach - wyniki badania ankietowego, „Współczesne problemy rachunkowości w teorii i praktyce”, Wydawnictwo Uniwersytety Warmińsko-Mazurskiego w Olsztynie, Olsztyn 2014, p. 98.

2 Based on consolidated financial statements of Globe Trade Centre for year 2014.
} 
and has been active on the real estate markets in the following countries: Poland, Romania, Serbia, Croatia, Bulgaria, the Czech Republic and Slovakia. Since the Group was founded, it has developed: 60 commercial properties, offering over $1,000,000 \mathrm{sq} \mathrm{m}$ of rentable area. Currently, the Group holds and manages 32 commercial properties, office and retail buildings, with the total net rentable area of $613,000 \mathrm{sq} \mathrm{m}$.

In the consolidated statement of financial position (balance sheet) at the end of 2012 the investment property constituted $71 \%$ of total assets while at the end of 2014 it was already $80 \%$; therefore, it is worth presenting here the measurement methods the company uses for such assets.

The Group's investment property is measured in accordance with IFRS 40; however, separate measurement methods are used for the investment property already held and the investment property under construction which in the future will be treated as investment property.

\section{1. Measurement of investment property by GTC S. A.}

GTC S. A. 's investment property includes land, buildings or parts of buildings held to earn rental income and/or for capital appreciation. In the financial statements, investment property is recognised at fair value according to the fair value model, which reflects market conditions at end of the reporting period. Gains or losses resulting from a change in the fair value of investment property are recognised in the income statement in the year they arise.

Completed investment property is valued by an independent valuer based on market data, using the DCF method (Discounted Cash Flow) or, if more appropriate, Income Capitalisation method or Yield method.

Investment property is derecognised from the statement of financial position when it has been disposed or withdrawn from use, and no future economic benefits are expected from its disposal. Any gains or losses on the retirement or disposal of investment property are recognised in the income statement in the year of retirement/ disposal.

Transfers of specific properties to investment property are made only when there is a change in use, evidenced by the end of owner-occupation or commencement of an operating lease to another party. Transfers of specific properties from investment property are made only when there is a change in use, evidenced by the commencement of owner-occupation or commencement of development with a view to sale.

\section{2. Measurement of investment property under construction by GTC S. A.}

The company measures only investment property under construction, for which a substantial part of risks related to its development has been eliminated. Assets, for which this is not the case, are recognised at the lower of cost and recoverable amount.

The following criteria have been adopted to assess whether substantial risks related to investment property under construction have been eliminated:

agreement with general contractor is signed;

construction permit is obtained;

at least $20 \%$ of rentable area is leased (based on signed agreements or letters of intent).

Fair value of investment property under construction is determined based on the progress of work at the end of the reporting period. Valuations are performed in accordance with the RICS ${ }^{1}$ and IVSC ${ }^{2}$ standards, using residual method approach, discounted cash flow or comparable transaction method, based on the valuer's judgement. Each investment property under

\footnotetext{
${ }^{1}$ A set of standards prepared by Royal Institution of Chartered Surveyors, generally used in Great Britain.

2 International Valuation Standards published by the International Valuation Standards Council.
} 
construction is assessed individually. The future value of assets is estimated based on expected future income from the project, using yields which are higher than current yields of comparable completed property. Expected remaining costs are deducted from the estimated future value of the assets. For projects where the expected future completion risk is above average (based on valuer's judgement), a developer's profit margin on uncompleted work is also deducted from their value.

\section{Summary}

The largest capital groups listed on the WSE measure their investment property under IAS 40, i. e. in accordance with the requirement imposed on such entities by the legislator. The conducted study shows that more than $50 \%$ of the entities hold investment property, and almost two thirds use the cost model to measure their investment property, i. e. measure it in the same way as tangible assets. The analysed entities apply the fair value measurement model less frequently, which may be related to the fact that it is more difficult to use, it has been in use for a short time, and it may also be related to the changes resulting from the

Introduction of a new standard - IFRS 13.

All analysed entities which hold investment property disclose information in the notes to consolidated financial statements. The disclosed information includes a list of investment property, its value at the beginning and at the end of the fiscal year, and a detailed list of changes resulting from acquisition or sale of assets, reclassifications as well as adjustments directly related to the applied measurement method. What is more, $60 \%$ of the entities which hold investment property also present income generated by such assets in the fiscal year in the notes, e. g. rental charges.

Although for $80 \%$ of the analysed entities investment property is not significant in the total statement of financial position, the scope of the disclosures is consistent with the requirements of IAS 40 and allows for assessing the asset and changes as well as a proper analysis of the data.

\section{References}

[1] Gabrusewicz W. (ed. ), Rachunkowość finansowa dla profesjonalistów, SKwP, Warszawa 2011.

[2] IFRS 13 - Fair Value Measurement, http://www. iasplus. com/en/standards/ifrs/ifrs13 (25. 07. 2015).

[3] International Financial Reporting Standards (MSSF), SKwP, Warszawa 2014.

[4] Karmańska A. (ed. ), Ryzyko w rachunkowości, Difin, Warszawa 2008

[5] MSR 40 - Międzynarodowy Standard Rachunkowości 40 - Nieruchomości Inwestycyjne z dnia 29. 11. 2008, Dziennik Urzędowy Unii Europejskiej, L. 320/323,

[6] Prewysz-Kwinto P., Voss G., Wykorzystanie MSSF 13 wycena w wartości godziwej w polskich przedsiębiorstwach - wyniki badania ankietowego, „Współczesne problemy rachunkowości w teorii i praktyce”, Wydawnictwo Uniwersytety Warmińsko-Mazurskiego w Olsztynie, Olsztyn 2014.

[7] Świderska G. K. (ed. ), Wzorcowy plan kont z komentarzem do ustawy o rachunkowości i Międzynarodowych Standardów Rachunkowości, Wolters Kluwer business, Warszawa 2012.

[8] The financial statements of entities included in the WIG-30 index: Alior Bank, Asseco Poland, Bogdanka, Boryszew, BZWBK, CCC, Cyfrowy Polsat, ENEA, ENERGA, EuroCash, Grupa Azoty, GTC, City Handlowy, ING Bank Ślaski, JSW, Kernel, KGHM, Lotos, LPP, mBank, Orange, PEKAO, PGE, PGNiG, PKN Orlen, PKO BP, PZU, Synthos, Tauron, TVN.

[9] Turyna J., Standardy Sprawozdawczości Finansowej, MSSF, US GAAP, polskie ustawodawstwo, Difin, Warszawa 2006 